\title{
How Ready is Renewable Energy? A Review Paper on Educational Materials and Reports Available for the Teaching of Hydrogen Fuel Cells in Schools
}

\author{
Tan Pey Fang ${ }^{*}, 1$, Wan Ramli Wan Daud², Lilia Halim³ ${ }^{3}$ Mohd Shahbudin Masdar ${ }^{4}$ \\ ${ }^{1}$ Centre for Engineering Education Research, Faculty of Engineering and Built Environment, Universiti Kebangsaan Malaysia 43600 \\ UKM Bangi, Malaysia
}

${ }^{2}$ Department of Chemical \& Process Engineering, Faculty of Engineering and Built Environment ${ }^{1}$, Fuel Cell Institute (SELFUEL), Universiti Kebangsaan Malaysia, 43600 UKM Bangi, Malaysia

${ }^{3}$ Department of Education Policy \& Leadership, Faculty of Education, Universiti Kebangsaan Malaysia 43600 UKM Bangi, Malaysia

${ }^{4}$ Department of Chemical \& Process Engineering, Centre for Engineering Education Research, Faculty of Engineering and Built Environment, Fuel Cell Institute (SELFUEL)², Universiti Kebangsaan Malaysia 43600 UKM Bangi, Malaysia

\begin{tabular}{l} 
A R T I C L E I N F O \\
\hline Article history: \\
Received: 10 February, 2020 \\
Accepted: 09 February, 2021 \\
Online: 10 March, 2021 \\
\hline Keywords: \\
Engineering education \\
RE \\
Hydrogen fuel cell teaching \\
programme \\
Covid-19 online learning
\end{tabular}

\section{Introduction}

Since the international oil embargo crisis in the 1970s that had threatened energy security of the world, the idea of developing

\footnotetext{
*Corresponding Author: Tan Pey Fang, tanpeyfang@gmail.com
}

\begin{tabular}{l} 
A B S T R A C T \\
Today, the costs of most Renewable Energy (RE) technologies especially hydrogen energy \\
technologies such as fuel cells, are still beyond the means of poorer economies in developing \\
countries. Hence, there is little public awareness and local expertise in RE in these countries \\
and even lesser in hydrogen energy. To solve this problem, it is important to train local \\
manpower in RE, starting with enabling local schoolchildren to learn about RE, especially \\
hydrogen fuel cells. RE provides an alternative, sustainable and clean energy that improves \\
the environment and human life, expands the choice of available energy sources that \\
improves energy security, and reduces consumption of fossil energy in electricity generation \\
and public transportation. Hence it is critical that teaching modules for exposure, \\
acceptance and uptake of RE technologies are developed to suit local conditions. The \\
purpose of this paper is to review recent progress and advances in RE education especially \\
in hydrogen fuel cell. Important features of the modules, educational materials and reports \\
are discussed critically. This paper assesses the literature on RE teaching in schools, \\
especially in hydrogen fuel cells, and discusses the problems faced and the optimal period \\
for cost-effectiveness. A curriculum that integrates literacy and social concepts with science, \\
technology, engineering and mathematics (STEM) concepts could be developed in the future. \\
The literature shows that teaching and learning of fuel cells could be achieved by using the \\
five "Es"; Engagement, Exploration, Explanation, Elaboration and Evaluation, and also by \\
promoting collaboration, team work, communication and design in project based learning \\
activities. Most teaching materials include a project for students to build their own single- \\
cell Proton Exchange Membrane (PEM) fuel cells and electrolyzers, and to produce \\
hydrogen by using solar energy. Appropriate and economic criteria are developed for the \\
design and development of modules for teaching and learning of hydrogen fuel cells, which \\
could be implemented in physical classrooms or on free blended online learning platforms \\
during the COVID-19 pandemic. \\
\hline
\end{tabular}

Renewable Energy (RE) has been widely acknowledged as a measure to stave off a recurrence of the embargo. The increasing acceptance of RE has been primarily attributed to the depletion of fossil fuels especially after the oil embargo crisis. Climate change 
caused by global warming due to carbon emission has been cited as the second most important driver for acceptance of RE. Climate change had manifested itself many times in extreme weather events such as intense heat waves that had hit several European countries such the UK in 2013 [1] and East Asian countries such as South Korea between 2009 and 2012 [2]. Acceptance of RE would reduce the effects of climate change.

Access to energy, energy efficiency and sustainability are the most popular issues in renewable energy (RE) [3]. RE has been found to have a controlling impact on carbon dioxide emissions and therefore climate change [4] and also a positive contribution to a country's economic production [4]-[6]. However, empirical evidence from sub-Saharan African countries have shown that the adoption of RE has not improved their economic power [7]. In addition, RE subsidies in advanced countries have resulted in high $\mathrm{RE}$ taxes to finance them that have imposed a heavy burden on consumers [8]. The economic gains and environmental costs of key energy materials such as rare earths are also important issues for and against RE technologies [9]. Furthermore, the high cost of renewable energy needs to be reduced significantly so that RE is no longer beyond the means of poorer economies in developing countries. For example the cost of RE biodiesel could be lowered by using low-cost renewable raw materials such as residual edible oil, inedible oil (Jatropha curcas and Camelina sativa) and seaweed [10].

The RE economy is a green economy that could provide significant employment in developing and developed countries [11]. In this case, employees and their leaders must be educated in green RE job markets. "Green-collar" workers play a vital role in the development of RE technologies. Students from various level ranging from technical and vocational diplomas in high schools, and science and engineering degree programs in universities could contribute to the sustainable development of the human resources for RE economy [11]. A Chinese study shows that there is a secondary relationship between $\mathrm{RE}$ and income [12].

Fuel cells convert chemical energy from molecular bonds in hydrogen and oxygen into electrical energy by an electrochemical reaction. A PEM (Proton Exchange Membrane) fuel cell or PEMFC uses hydrogen gas $\left(\mathrm{H}_{2}\right)$ and oxygen gas $\left(\mathrm{O}_{2}\right)$ from the air in the reaction and produces electricity, water, and heat. Currently research on PEMFC is focused on developing proton exchange membranes that could operate at high temperature for the Hightemperature Proton Exchange Membrane Fuel Cell (HT-PEMFC) [13]. If hydrogen is produced using RE, the green hydrogen so produced could be classified under RE as well.

For Malaysia to stand out in RE technology, there is an urgent need to introduce and integrate RE education into the educational curricula in schools. Although teachers' knowledge content on RE could easily be developed to a satisfactory level, RE education might repeat a major pitfall in science education in Malaysia, which is the inability of science teachers to transfer their knowledge content to the students effectively [14]. Therefore, an essential goal of science or engineering education is to enable these teachers to convey their knowledge to students effectively.
Table 1: Nomenclature Table

\begin{tabular}{|l|l|l|}
\hline No. & Abbreviation & Explanation \\
\hline 1 & STEM & $\begin{array}{l}\text { Science, Technology, Engineering and } \\
\text { Mathematics }\end{array}$ \\
\hline 2 & RE & Renewable Energy \\
\hline 3 & PEMFC & Proton Exchange Membrane Fuel Cell \\
\hline 4 & HT-PEMFC & $\begin{array}{l}\text { High-temperature Proton Exchange } \\
\text { Membrane Fuel Cell }\end{array}$ \\
\hline 5 & FC & Fuel Cell \\
\hline 6 & HFEP & Hydrogen Fuel Cell Education Program \\
\hline 7 & DO & Design Opportunity \\
\hline 8 & EiE & Engineering is Elementary \\
\hline 9 & STEAM & $\begin{array}{l}\text { Science, Technology, Engineering, } \\
\text { Arts, and Mathematics }\end{array}$ \\
\hline 10 & FCVs & Fuel Cell Vehicles \\
\hline
\end{tabular}

This is the first paper in Malaysia to review the readiness of RE education and its educational materials, and available reports on the teaching of hydrogen fuel cell in schools, with the intention of developing teaching modules that could be implemented in the physical classroom. When the COVID-19 pandemic began, there is an urgent need to design and develop modules for teaching and learning hydrogen fuel cells that could be implemented not only in the physical classroom but also conducted online to avoid the pandemic, that is free for all urban and rural children. The authors examine the suitability of these materials to be implemented in the physical classroom and online learning.

The review is intended to provide information, insights and intuitions which would lead the authors and other researchers to develop a cost-effective and economic teaching and learning of hydrogen fuel cells in the country and/or the region. The teaching and learning materials could be transformed into the online learning courses, that is free for everyone. In addition, the blended, interactive online courses with a curriculum created by educators for students and for educators could have the potential of encouraging independent learning, collaboration on projects and hassle-free grading assignments, free for all urban and rural schoolchildren/educators anywhere and at any level, who could learn and stay safe online, avoiding the pandemic.

In this study, we focus upon the recent progress and advances of RE education materials. First, we summarize the objectives of Fuel Cell (FC) education. Then we review the recent features of Hydrogen Fuel Cell Education Program (HFEP) including the teaching method for STEM which includes engineering design, problem solving, collaboration, teamwork, communication and project work. In this part, the science process skills, the design opportunity (DO) element and the design brief which are very important to design and generate solutions to specific problems are 
systematically discussed. We also discussed about the recent development in design brief for a project given to the students. Finally, a short conclusion which includes the future perspectives of this RE education materials and challenges in practical application, the cost-effective features and flexibility to be used in blended learning during pandemic crisis are constructively analyzed.

\section{Hydrogen Fuel Cell Education Program (HFEP)}

\subsection{HFEP Objectives}

Since the fate of the Earth is in the hands of children, it is crucial and important for them to learn to use RE, and in our case green hydrogen energy and fuel cells at an early age in schools. The main aim of educating schoolchildren on fuel cells and hydrogen energy is to familiarize them with hydrogen energy and fuel cells technology, which would lead to a better, more sustainable, and inhabitable world. The objectives of the HFEP could be summarized as follows

- To accelerate the exposure to fuel cell technology among the schoolchildren

- To encourage the young, who could become future scientists, to perceive fuel cell as an important green energy alternative

\subsubsection{Engineering Teaching Method of HFEP}

To ensure that the teachers transfer their knowledge content on hydrogen fuel cells effectively to students, a more effective teaching method should be used. One such effective method that we intend to consider is the teaching method for engineering. The teaching method for engineering as suggested by [15], consists of the following fundamental components.

Firstly, the Learning Cycle is summarized as the 5 Es: Engagement, Exploration, Explanation, Elaboration and Evaluation. This is very similar to Bloom's cognitive taxonomy. The first $\mathrm{E}$ is Engagement where students are challenged and thought-provoked by reading aloud stories to stimulate imagination and to encourage sharing of ideas. The second $\mathrm{E}$ is Exploration where students are encouraged to discover scientific and engineering principle by themselves. This is followed by the third $\mathrm{E}$ for Explanation where students explain what happen in different situations and learn from them. The fourth $\mathrm{E}$ is Elaborations where students use the knowledge gained to design engineering artefacts. The final $\mathrm{E}$ is evaluation where students reflect on their learning curve [15].

Secondly engineering teaching method is contextual learning and problem solving that link their knowledge with the real world by application in problem solving. Thirdly, learning engineering also involves teamwork and collaborative learning in small groups. Fourthly students are also trained in effective communications between team members, clients, and managers. Lastly the engineering teaching method always involve a design project by student that applies all the knowledge that has been learned [15],

The Engineering is Elementary: Engineering and Technology Lessons for Children (EiE) project for American schoolchildren launched in 2003 was a success because it embeds curiosity in the mind of the schoolchildren [16]. EiE not only meet the needs of children, but also expand the ability of primary educators to teach engineering technology. After the EiE project was launched, the number of schools in the United States that embrace engineering in their curricula increased dramatically.

\subsubsection{Science process skill}

The amount of knowledge that can be obtained from the teaching of comprehensive Science, Technology, Engineering and Mathematics (STEM) is related to how students perceive the effects of STEM teaching [17]. In Thailand, although a high degree of understanding of scientific ideas and concepts and exceptional presentation of scientific process skills are essential for learning science, most Thai teachers have managed to obtain satisfactory performance for these scientific process skills. These include starting the course by sharing the relevant day-to-day situations of the students, grouping the students into groups, making hypotheses, finding information and planning experiments, conducting experiments, collecting data, explaining and summarizing the results. Then share the results with the class, visit the gallery where experimental conclusions are shown, discuss the class summary, and finally determine the possible sources of errors. To succeed, they start with selective science courses, which have less content, so that they could focus more on encouraging skills related to students' abilities and interests[18].

\subsubsection{Important features of the engineering design component of a curriculum}

The important features engineering design component include encouraging student creativity, following proven design, open ended problems, search for and use contemporary theories, problem statement and specifications, awareness of alternative solutions, and real-world applications [19].

The features of RE education are flexible and amenable to evaluation by both qualitative and quantitative methods. The DO part is more important than a paper and pencil assessment, while collaborative learning and teamwork are prioritized over individual work. Communication skills are essential in engineering education to prepare future engineers. Students must design and find a solution to a problem. After each session, students share their insights on the learning process and make deep reflections.

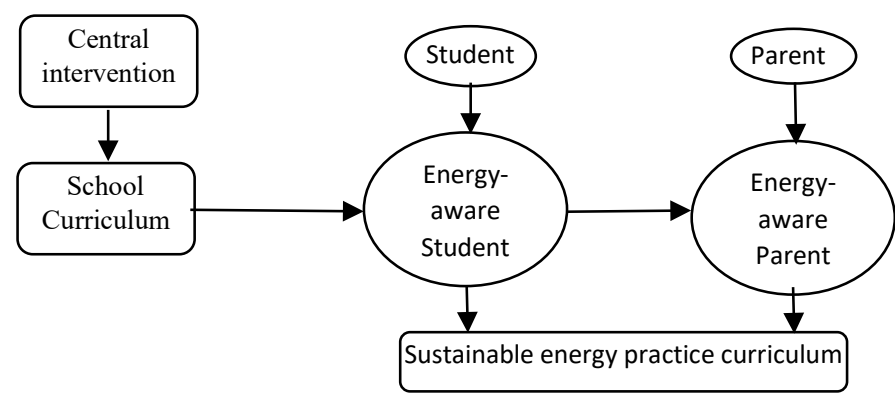

Figure 1: Energy related education channel in society [20]

Experimental work is a large component of learning science and engineering. However, learning how to build a fuel cell does not need to start with complicated experimental works. Hurley (2010) believed that anyone with minimum skills and tools will 
be able to build high quality fuel cells from readily available materials. Construction of the cells requires a few hand tools only. Apart from setting up a PV solar panel to generate power for the electrolyzer, he also used the "heart" of the fuel cell, namely, the Membrane Electrode Assemblies (MEAs). In 2013, Hurley published a manual that provides five templates for students to build a solar hydrogen fuel cell system and a fuel cell stack. The components include 40-watt solar panels to run the electrolyzers for generating hydrogen fuel, a simple hydrogen storage, and a 6to 12-watt planar hydrogen FC stack for generating electricity.

A well designed complete curriculum or enrichment programme is able to educate the students to create a sustainable energy practices lifestyle [20]. Energy-aware students could influence their parents to create energy-aware parents. It is going to be a chain reaction, a domino effect, or a snowball effect in the society.

In one study, parents of 16 years old upper secondary rural children, who had just enrolled to study pure science subjects, were found to have acquired positive values towards science and were willing to support and assist their children to improve their achievements in science. These are crucial factors that can help the educationists to plan RE educational intervention involving parents' support in promoting RE learning and careers [21].

\subsection{Design Brief}

Practical science activities are insufficient in helping students achieve all their learning objectives. Although design task is given to students in groups of two to four, it is better to wait until everyone has their own design ideas before breaking them into groups. Students must be given freedom to carry out their own investigations or create their own designs to Brown's module. This requires a combination of individual learning opportunities [22], which is could be done in two formats where the students must determine the steps required to achieve their goals, or specific steps were outlined for an experiment. After finalizing team designs, students continue with construction, testing, and presentation preparation and project presentations[22].

Another program that emphasizes the importance of engineering design process as the heart of engineering is EiE. By creating and testing lessons that are closely integrated with elementary science topics, EiE aims to strengthen the science program by integrating it with main engineering concepts, broaden their interests, expand children's images of engineering, fostering positive attitudes towards engineers and expectations for the future. Apart from developing curricular materials and resources, the EiE also conducts workshops for educators in the US. Engineers and teachers are involved in the development of a classroom-tested curriculum. The curriculum also integrates literacy and social concepts with science, mathematics, and engineering concepts [16].

\subsection{Integration of Engineering Elements in the Modules}

Unlike science, the arts played a large role in the history of engineering. Design, the heart of engineering, is more like arts than science. Modern engineering has also benefited much from science and mathematics. Both fields help the engineer to understand how engineering artefacts behave by simulating mathematically the scientific principles at work in the artefact. Scientific discoveries also provide opportunities for engineers to design novel products that harness the new scientific discoveries to commercialize scientific/engineering products, the arts is used to repackage the product in a much more elegant and attractive manner for the market.

For example, the cell phone is a blend of science, engineering and art. In car industry, science makes the combustion engine work efficiently, while the artistic design of the car complements the masterpiece. In the performing arts, art does not merely refer to acting or singing on the stage but also involves the technology being used at the back-stage.

However, it was only recently that the arts has been integrated into STEM (Science, Technology, Engineering, and Mathematics) to become STEAM (Science, Technology, Engineering, Arts, and Mathematics). An educated person must be able to appreciate art and embrace technology at the same time. The fuel cell is both an engineering and scientific artefact whose invention and design also include the arts.

\subsection{Engineering Elements}

To integrate engineering elements into the modules, Hershey [23] suggested that students must always be directed by providing them with stimulus after understanding the inventive procedure. The aim of inventing new engineering products should be to improve, enhance, and expand mainstream products to meet social needs. It is important to highlight the importance of merging combinations of elements of many prevailing products to create new products. New opportunities should be recognized by ignoring the rules and using and testing the system. The invention must be "futurized" to ensure the products are up to date. Improve understanding of regulations and use them for innovation. Finally, after completing the invention, you must gather information regarding patent application to protect their rights on the product.

\subsection{Economic Features}

The experiment or hands-on work need to be simplified by reducing the parts needed so that anyone with minimum skills, tools and materials will be able to produce the product in the teaching manual [24]. A well-designed complete curriculum or programme must be able to educate school children by exposure to $\mathrm{RE}$ and $\mathrm{FC}$ in an optimal period of time, whose characteristics had been futurized so that it could be updated to suit contemporary circumstances. The teaching module could be implemented in the physical classroom and/or online using blended learning platform that is safe and that eliminates the costs for venue, transportation, etc during pandemic.

\section{Hydrogen fuel cells' impacts on securing energy sources and maintaining environmental sustainability}

It is important to diversify the types of RE, rather than just relying on specific types. When land and other inputs are transferred from food crops to biodiesel production, the biodiesel industry may lead to competition between fuel and food. [25], 
[26]. The biodiesel and oleochemical industries need similar raw materials, which increases their prices. The introduction of biodiesel will directly cause an excessive supply of glycerin, and indirectly lead to a scarcity of oleochemical industry. The glycerin produced must be converted into other useful products. In turn, excessive glycerin will make the price to drop [25].

Malaysia, a major producer of palm oil, produces a lot of wastewater known as the palm oil mill effluent (POME) and empty fruit bunches (EFB) biomass. The adverse impacts of POME towards the environment could be mitigated by reusing the water to overcome water scarcity but reclaiming the water from POME involve cost [27]-[29]. Water treatment by reverse osmosis desalination plants instead of the coventional water treatment plants, incurs higher cost for the integrated/hybrid membrane processes. Usually, a more complicated process is needed for POME treatment such as combinations of membrane filtration unit (microfiltration/ultrafiltration/nanofiltration) with other processes such as adsorption, coagulation, adsorption and ion exchange. [28]. Additionally, natural coagulants could be used with other treatment technologies in integrated/hybrid treatment processes for improved coagulation performance efficiency [29].

Malaysia, a major producer of palm oil, has great potential for $\mathrm{H}_{2}$ production from POME and EFB biomass by biological treatment but the dark fermentation also produces $\mathrm{CO}_{2}$ simultaneously. The process is not sustainable until a more reliable and efficient process for separating $\mathrm{H}_{2}$ from $\mathrm{CO}_{2}$ is devised and a process to store or reuse the $\mathrm{CO}_{2}$. The purified $\mathrm{H}_{2}$ from the gas mixture could be used as a clean source for RE such as in a hydrogen FC [30], [31]. The biogas produced from the further fermentation of POME is already a source of energy around the palm oil mill and could potentially be a major source of RE for Malaysia [31]. Methanol, another fuel for fuel cells, could also be produced from EFB biomass. Methanol FC can be directly applied in mini air vehicles [32].

The success of any bioenergy project is not only determined by technical viability but also by non-technical factors such as authorities, engineers, feedstock producers, and the concerned public [33]. Students have little introduction and experience with hydrogen fuel cells. Hence, students' perception of environmental friendliness of hydrogen fuel cells falls to the eighth, below solar, wind, hydro, wave, natural gas, tidal and geothermal. See Tab. 1 [34].

Table 2: Student perception of environmental friendliness of energy sources (in percent)

\begin{tabular}{|l|r|r|l|r|r|c|}
\hline Energy Sources & \multicolumn{1}{l|}{$\begin{array}{l}\text { Not } \\
\text { Friendly }\end{array}$} & $\begin{array}{l}\text { Little } \\
\text { friendly }\end{array}$ & $\begin{array}{l}\text { Less or more } \\
\text { friendly }\end{array}$ & Friendly & $\begin{array}{l}\text { Very } \\
\text { friendly }\end{array}$ & $\begin{array}{l}\text { Friendliness } \\
\text { rank }\end{array}$ \\
\hline Natural gas & 4.7 & 10.3 & 32.5 & 33.8 & 18.8 & $5(52.6)$ \\
\hline Solar power & 2.6 & 5.1 & 8.1 & 26.9 & 57.3 & $1(84.2)$ \\
\hline Hydropower & 3.8 & 11.5 & 24.4 & 29.9 & 30.3 & $3(60.2)$ \\
\hline Wind power & 4.3 & 7.3 & 12.4 & 21.4 & 54.7 & $2(76.1)$ \\
\hline Geothermal power & 4.3 & 16.7 & 33.3 & 25.6 & 20.1 & $7(45.7)$ \\
\hline Nuclear power & 56.8 & 16.7 & 16.7 & 5.1 & 4.7 & $14(9.8)$ \\
\hline Coal & 47.0 & 23.1 & 17.9 & 5.6 & 6.4 & $13(12.0)$ \\
\hline Oil & 58.5 & 18.4 & 9.0 & 4.7 & 9.4 & $12(14.1)$ \\
\hline Wave power & 9.8 & 15.4 & 21.4 & 26.1 & 27.4 & $4(53.5)$ \\
\hline Tidal power & 5.6 & 20.1 & 28.6 & 24.4 & 21.4 & $6(45.8)$ \\
\hline Biofuel & 20.1 & 22.2 & 24.8 & 25.2 & 7.7 & $9(32.9)$ \\
\hline
\end{tabular}

\begin{tabular}{|l|r|r|c|r|r|l|}
\hline Waste (buming) & 41.9 & 23.9 & 16.7 & 132 & 4.3 & $11(17.5)$ \\
\hline Biomass & 14.5 & 24.4 & 28.2 & 22.2 & 10.7 & $9(32.9)$ \\
\hline Biogas & 11.5 & 20.9 & 37.2 & 21.4 & 9.0 & $10(30.4)$ \\
\hline $\begin{array}{l}\text { Hydrogen fuel } \\
\text { Cells }\end{array}$ & 16.2 & 18.8 & 26.9 & 20.5 & 17.5 & $8(38)$ \\
\hline
\end{tabular}

Sources:[34]

\section{Number of textbooks or references available for teaching fuel cell}

For design projects, no manuals, textbooks or workbooks have been provided for students [15], [16] Instead, there are five EiE steps of engineering design process that must be followed: ask, imagine, plan, create, and improve solutions to the given engineering challenges. After the project is accomplished, evaluation is carried out by using a combination of qualitative and quantitative measures.

A Textbook on the introduction of RE technologies in the United States have been published [32]. The one-year science and technology course contain 11 modules. The author associated energy science, fossil fuels and climate change, explores the use and preservation of energy in houses, and establishes energyefficient energy sources such as solar energy, energy wind energy, hydrogen and fuel cells, biomass energy, biofuels, geothermal energy and hydropower.

Hydrogen fuel cells have attracted widespread attention, and its applications in sustainable transportation have been debated. An introduction to hydrogen is provided, followed by a project for students to build their own fuel cells. The fuel cell kit that includes PEMFC and electrolyzers, could be bought from www.fuelcellstore.com. The student would also need a small solar PV panel to provide the energy to produce the hydrogen. Students are given a fuel cell invention design brief. After students complete their team's mission, each team had three to five minutes to introduce their project. The teams then develops special product handbooks for the inventions. After studying all types of RE, the "RE Final Project" is conducted in 10 to 45 minutes of teaching time or five stages of teaching time. Based on the selected RE source, students developed and tested their design brief. Students not only introduced their projects to the class, but also introduced their projects to school members and local public [32].

The number of textbooks on substitute energy and sustainable energy in the region and the rest of the world is very inadequate. More textbooks need to be written according to local conditions to speed up the adoption of RE in the region. The fundamental physical and technical principles of RE to generate energy, and its impact on the socio-economic and environmental.

\section{Country Comparison in Terms of Their Readiness to Embrace FC Technology}

After the hydrogen fuel cell is identified as one of the most sustainable, clean and efficient energy sources, the next century is predicted to become the hydrogen era [48], [49]. Hydrogen Fuel Cell Vehicles (FCVs) are expected to have a key influence in energy security and preservation of environmental sustainability. 
Table 2: FC Education Materials and Reports Available

\begin{tabular}{|c|c|c|c|}
\hline Name & Link and Contact & Synopsis & Educational Level \\
\hline $\begin{array}{l}\text { "Build Your Own } \\
\text { Fuel Cells" }\end{array}$ & $\begin{array}{l}\text { http://physics.csusb.edu/ tusher/ } \\
\text { share/Fuel_Cell/build_fuel_cells } \\
\text { 05.pdf [35] }\end{array}$ & $\begin{array}{l}\text { Hard / soft convection single slice fuel cell } \\
\text { construction. Fuel cell design. }\end{array}$ & $\begin{array}{l}\text { Adults and tenants (not appropriate } \\
\text { for children without close supervision } \\
\text { of adults familiar with fuel cells) } \\
\text { Reached more than } 9,600 \text { teachers }\end{array}$ \\
\hline $\begin{array}{l}\text { "Education And } \\
\text { Outreach (By Fuel } \\
\text { Cell Technologies } \\
\text { Office)" }\end{array}$ & $\begin{array}{l}\text { https://www.energy.gov/sites/pr } \\
\text { od/files/2014/05/f15/fcto educat } \\
\text { ion_and_outreach.pdf [36] }\end{array}$ & $\begin{array}{l}\text { Professional development for teachers } \\
\text { Seven video clips } \\
\text { - Developed a two-week study plan. } \\
\text { High school student module } \\
\text { K-12 project goals } \\
\text { - Provide tutoring and training. } \\
\text { For the hydrogen and fuel cell future generation of } \\
\text { labour market } \\
\text { - Together with current K-12 school curriculum, test } \\
\text { the developed hydrogen and FCtechnology } \\
\text { - Introduction to hydrogen science } \\
\text { and technology in the highschools and primary schools } \\
\text { classroom } \\
\text { - Run professionals } \\
\text { development plan for } \\
\text { high school and primary school teachers } \\
\text { who will use the course materials } x \\
\text { Determine the superiority and efficiency of the course } \\
\text { materials } \\
\text { - Expand communication chances with } \\
\text { new companion } \\
\text { - Distribute the curriculum and workshops apparatus } \\
\text { to the whole country } \\
\text { via teachers' training and other training } \\
\text { programme. }\end{array}$ & Reached more than 9,600 teachers \\
\hline $\begin{array}{l}\text { "Washington State } \\
\text { Fuel Cell Education } \\
\text { and Demonstration } \\
\text { Program } \\
\text { (DOE Hydrogen } \\
\text { Program)" }\end{array}$ & $\begin{array}{l}\text { https://www.hydrogen.energy.go } \\
\underline{\text { v/pdfs/progress04/vii3_vowles.p }} \\
\underline{\text { df [37] }}\end{array}$ & $\begin{array}{l}\text { Develop FCcourses for high schools. } \\
\text { Trained } 200 \text { junior and senior high school teachers on } \\
\text { hydrogen and fuel cells } \\
\text { - Provide hydrogen and fuel cell teaching to } 18,000 \\
\text { high school students in Washington State. } \\
\text { - Assess the efficiency through an online } \\
\text { questionnaire. } \\
\text { Proton exchange membrane fuel cell (PEM) } \\
\text { demonstration at Central Washington University. } \\
\text { - Offer college students with an internship to learn } \\
\text { about fuel cells. }\end{array}$ & $\begin{array}{l}\text { Train } 200 \text { junior and high school } \\
\text { teachers and develop high school } \\
\text { curriculum. }\end{array}$ \\
\hline $\begin{array}{l}\text { "DOE Hydrogen } \\
\text { Program. } 2004 \\
\text { Annual Program } \\
\text { Review } \\
\text { Education } \\
\text { Overview" }\end{array}$ & $\begin{array}{l}\frac{\text { https://www.hydrogen.energy.go }}{\text { v/pdfs/review04/ed 1 cooper } 0} \\
\text { 4.pdf }[38]\end{array}$ & $\begin{array}{l}\text { Reach a fourfold increase in the number of students } \\
\text { and teachers } \\
\text { who understand the concept of hydrogen economics } \\
\text { and its impact on hydrogen economics } \\
\text { Reach a fourfold growth in the number of state and } \\
\text { local government councils who } \\
\text { know the idea of hydrogen economy and how } \\
\text { this economy can influence them } \\
\text { Double the number of big-scale end users who } \\
\text { understand the concept of hydrogen economics and its } \\
\text { impact on them } \\
\text { awareness campaign pertaining } \\
\text { Hydrogen economy and fuel cell technology }\end{array}$ & $\begin{array}{l}\text { Teachers and students; } \\
\text { public }\end{array}$ \\
\hline $\begin{array}{l}\text { "Tykey Truett Oak } \\
\text { Ridge National } \\
\text { Laboratory 2004 } \\
\text { DOE Hydrogen, } \\
\text { Fuel Cells \& } \\
\text { Infrastructure } \\
\text { Technologies } \\
\text { Program Review } \\
\text { Baseline Program } \\
\text { Assessment" }\end{array}$ & $\begin{array}{l}\text { https://www.hydrogen.energy.go } \\
\text { v/pdfs/review04/ed_2 truett 04. } \\
\text { pdf [39] }\end{array}$ & $\begin{array}{l}\text { Measure the existing level of awareness; establish a } \\
\text { benchmark for evaluation }\end{array}$ & $\begin{array}{l}\text { General public; } \\
\text { State and local government agencies; } \\
\text { educators, students and } \\
\text { Possible important consumers }\end{array}$ \\
\hline
\end{tabular}




\begin{tabular}{|c|c|c|c|}
\hline $\begin{array}{l}\text { "Fuel Cell } \\
\text { Demonstration with } \\
\text { Onsite Generation } \\
\text { of Hydrogen" }\end{array}$ & $\begin{array}{l}\text { https://www.hydrogen.energy.go } \\
\text { v/pdfs/review04/ed_p1_turner_0 } \\
\underline{\text { 4.pdf }[40]}\end{array}$ & $\begin{array}{l}\text { Awareness and education } \\
\text { Demonstration of hydrogen fuel. } \\
\text { Zero emissions from source to sink }\end{array}$ & $\begin{array}{l}\text { Introduce hydrogen in the } \mathrm{K}-12 \\
\text { education plan; } \\
\text { Launch public awareness program; } \\
\text { University }\end{array}$ \\
\hline $\begin{array}{l}\text { "Development And } \\
\text { Demonstration of } \\
\text { PEM Fuel Cell } \\
\text { Educational } \\
\text { Program For School } \\
\text { and University } \\
\text { Communities" }\end{array}$ & $\begin{array}{l}\text { https://www.hydrogen.energy.go } \\
\text { v/pdfs/review04/ed_p3_peters_0 } \\
\underline{\text { 4.pdf [41] }}\end{array}$ & $\begin{array}{l}\text { Development and operation task } 1 \text { - Development and } \\
\text { operation of educational courses. }\end{array}$ & $\begin{array}{l}\text { Middle school, high school, teachers, } \\
\text { community and government leaders. }\end{array}$ \\
\hline $\begin{array}{l}\text { "The } 2004 \text { DOE } \\
\text { Hydrogen, Fuel } \\
\text { Cells and } \\
\text { Infrastructure } \\
\text { Technologies } \\
\text { Program Review } \\
\text { Lansing } \\
\text { Community College } \\
\text { Alternative Energy } \\
\text { Initiative" }\end{array}$ & $\begin{array}{l}\text { https://www.hydrogen.energy.go } \\
\text { v/pdfs/review04/ed_p4 borger } \\
\text { 04.pdf [42] }\end{array}$ & $\begin{array}{l}\text { Advocate National Energy Policy to } \\
\text { Integrate in energy sources that are dependable, } \\
\text { economic and ecologically } \\
\text { embrace the future of America. } \\
\text { Improve explosure and knowledge of alternatives } \\
\text { Including the energy from hydrogen fuel cells. } \\
\text { - Create } \\
\text { comprehensive training Program for } \\
\text { technicians who can support alternatives } \\
\text { energy technologies as an effort to increase feasibility } \\
\text { and spread } \\
\text { RE technology } \\
\text { Utilise the new West Campus educational facilities to } \\
\text { display } \\
\text { other energy applications consist of: } \\
\text { i)Wind; } \\
\text { ii)Solar energy; } \\
\text { iii)Geothermal } \\
\text { iv)Biomass and } \\
\text { v)Fuel cell }\end{array}$ & Workforce (including K-12). \\
\hline 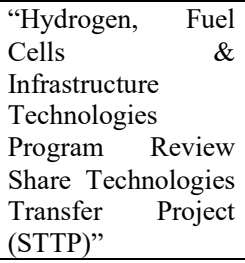 & $\begin{array}{l}\frac{\text { https://www.hydrogen.energy.go }}{\text { v/pdfs/review04/ed_p5_griffin.p }} \\
\underline{\text { df }[42]}\end{array}$ & $\begin{array}{l}\text { Cooperative process with the national industry to share } \\
\text { technology developed by the Navy; } \\
\text { Raise awareness of private companies to } \\
\text { hydrogen and FC including Infrastructure Technology } \\
\text { (hydrogen) Program }\end{array}$ & $\begin{array}{l}\text { Manufacturing and university } \\
\text { educators. }\end{array}$ \\
\hline $\begin{array}{lr}\text { "Montana } & \\
\text { Hydrogen } & \text { Futures } \\
\text { Project } & \text { (New } \\
\text { Project)" } & \end{array}$ & $\begin{array}{l}\text { https://www.hydrogen.energy.go } \\
\text { v/pdfs/review04/ed_p6_bromens } \\
\text { henk_04.pdf [43] }\end{array}$ & $\begin{array}{l}\text { Highlight hydrogen technologies in the } \\
\text { development of } \\
\text { educational plans and facilities when } \\
\text { training energy technicians } \\
\text {; } \\
\text { Hydrogen Safety Center; } \\
\text { education / interactive website for training or } \\
\text { communication }\end{array}$ & Energy Specialist \\
\hline $\begin{array}{l}\text { "Fuel Cells } 2000 \text {--- } \\
\text { Fuel Cell for } \\
\text { Education" }\end{array}$ & $\begin{array}{l}\text { https://www.utc.edu/college- } \\
\text { engineering-computer- } \\
\text { science/pdfs/fuel-cells-for- } \\
\text { education.pdf [44] }\end{array}$ & List of existing corporations and educational products. & All school and academia levels. \\
\hline "leXsolar-H2" & $\begin{array}{l}\text { https://lexsolar.com/products.ht } \\
\text { ml?isorc }=755[45]\end{array}$ & Directory of course packages on RE. & All schools and TVET levels. \\
\hline $\begin{array}{l}\text { "MudWatt NGSS } \\
\text { Teacher's Guide" }\end{array}$ & $\begin{array}{l}\text { http://www.fuelcellstore.com/do } \\
\text { wnloads/mfc/mudwatt-main- } \\
\text { module.pdf [46] }\end{array}$ & $\begin{array}{l}\text { Microbial Fuel Cell (MFCs) } \\
\text { Training Module }\end{array}$ & Junior high schools \\
\hline $\begin{array}{l}\text { "Implementation of } \\
\text { the MudWatt"M } \\
\text { Microbial Fuel } \\
\text { Cell" }\end{array}$ & $\begin{array}{l}\text { http://www.fuelcellstore.com/do } \\
\text { wnloads/mfc/nsf-mudwatt- } \\
\underline{\text { module.pdf [47] }}\end{array}$ & $\begin{array}{l}\text { Assembly of MudWatt TM sediment microbial FCby } \\
\text { students teach them how to generate energy through } \\
\text { electrochemical reactions. }\end{array}$ & Physical Science class (9th grade) \\
\hline
\end{tabular}

An effective transition to a sustainable energy system requires public and private sector funding. Many studies have investigated the Purchase Intention (PI) and buying behaviour of hydrogen FCVs and Alternative Fuel Vehicles (AFCs) in Malaysia. Many researchers have started studying hydrogen FC vehicles, while others have conducted rigorous reviews of whether attitudes, subjective norms (SN), and control of perceived behaviour are related to customers' Purchase Intentions (PI) and whether there is a significant association with Purchase behaviour of hydrogen FCVs in Malaysia. These studies are very important for the 
decarbonization of the transportation sector in Malaysia and other countries under similar economic conditions[50].

\subsection{Malaysia}

Of the more than 10,000 schools in Malaysia, about 809 have no power for the whole day, which is particularly common in Sabah and Sarawak. RE sources such as solar panels, wind turbines and micro hydropower plants can meet the electrification needs of rural areas. Take the Penontomon Elementary School (N $\left.4^{\circ} 52.73^{\prime} \mathrm{E} 116^{\circ} 15.9^{\prime}\right)$ in the Sabah as an example. A solar wind hybrid system was installed to power the guardhouse, tutorial room, computer laboratory and teacher quarters [51]. Before Malaysia can absorb hydrogen fuel cells on a large scale, much work remains to be done.

The biggest benefit of hydrogen is zero emissions, which could help Malaysia achieves the COP15 carbon emission target. Primary energy resources can be used to produce hydrogen in many ways. Hydrogen can be used for transportation, has portable and stationary applications, and could replace fossil fuels [32].

Research and development in hydrogen energy and fuel cells in Malaysia started in Universiti Kebangsaan Malaysia (UKM) in 1995. It was kick-started when a large project of RM 2 million was awarded jointly to UKM and Universiti Teknologi Malaysia (UTM) in 1996 for 5 years from the Intensification of Priority Research (IRPA) fund from Ministry of Science, Technology \& Innovation (MOSTI). The same team was granted a much larger project that is 15 fold larger than the first one amounting to RM30 million from the same fund and Ministry in 2002 for 5 years. UKM and UTM team won another large grant of RM7 million from the Ministry of Higher Education (MOHE) in 2013 for 3 years.

It was with this fund that the Fuel Cell Institute (FCI) was established in UKM. The research and development done at FCI are fuel cell system engineering (PEMFC systems), fuel cell electrochemical processes, photoelectrochemical cells, solid oxide fuel cells, direct liquid fuel cells, microbial fuel cells, hydrogen production and solid-state storage and biohydrogen.

Yayasan Sime Darby (Sime Darby Foundation) gave an endowment of RM15 million to establish the UKM-YSD Chair For Sustainable Development: Zero Waste Technology to conduct research and development on hydrogen and biogas production from POME and EFB biomass for power and steam generation, UKM-YSD Chair in collaboration with FCI UKM built a pilot demonstration plant for biohydrogen and biogas production from POME and EFB biomass, $\mathrm{CO}_{2}$ separation and hydrogen purification and $\mathrm{CO}_{2}$ storage in algae at a Sime Darby's KKS Tennnamaram, Selangor, Malaysia. A FC buggy is also built to use hydrogen produced by the pilot plant [52].

Recently, Petronas Research Sdn Bhd (PRSB) has granted a large research project of RM 8.25 million to establish the UKMPetronas Chair of Sustainable Hydrogen Energy in 2019 to conduct research and development on green hydrogen production technology for 5 years. PRSB-UKM is developing new type of electrolyzers at pilot plant scale and plans to built a large FC buggy and start research and development of photoelectrochemical cells.

The extensive R\&D of fuel cells and hydrogen energy in Malaysia over 25 years warrants the introduction of fuel cells and hydrogen energy in the school curriculum in Malaysia. Using a battery and FC based system, a project was carried out in a municipal house in Kapit Village, Sarawak [53]. The same configuration can be used for schools in remote areas in other states of Malaysia. Some Malaysian institutions promoting hydrogen FC education mainly focus on PEMFC technology to provide energy for single-seater vehicles [54]. Following the launch of the fuel FC golf buggy of the FCI UKM and the fuel cell/hybrid electric scooter of Taiwan Chengda National University [36], educators can improve the application of fuel cells by introducing FC programs in their schools through an engineering design teaching module[55].

\subsection{Japan}

Japanese automakers Honda and Toyota have begun to introduce fuel cell vehicles into their products range [56], [57], [58]. The public showed a positive attitude towards hydrogen infrastructure, but expressed concern about the balance between risk of hazards and benefits brought by FC vehicles [59]. An online study conducted to determine the public's attitude towards installing hydrogen refueling stations near residential areas shows that gender gap need to be reduced through education because men accepted more than women. [60].

\subsection{Taiwan}

In recent decades, the Taiwan government has actively encouraged FC invention through the national invention system. In [49], vocational education and training (VET) is usually a significant subsystem. Many academic and research institutions in Taiwan have also defined policy tools related to VET[49].

\subsection{Africa}

In the Eastern Cape Province of South Africa, numerous primary and secondary schools have started to apply hydrogen fuel cells to generate energy reserves. This power supply is used to power devices such as computers, fax machines, and tablets [61].

\subsection{US}

In Woodbridge, Connecticut, Amity Regional High School uses FC energy to generate $2.2 \mathrm{MW}$ of combined heat and power (CHP). There were fuel cells with small 1.4 MW CHP used in Santa Rita Jail in California [62]. FC teaching not only in schools and universities but extended to national level. The California Fuel Cell Partnership and the Pacific Northwest National Laboratory have conducted hydrogen safety first aid training programs for more than 15 years [63]. The resources developed can be used for advanced general lectures or classroom training, depending on the level of understanding of the demographic of the target group [64].

\subsection{European Union (EU)}

In 2010, school students in Europe did not learn hydrogen and fuel cells in formal education. There are few textbooks about 
hydrogen and fuel cells, and plans are made to introduce hydrogen as a suitable future energy source for transportation sector [65]. In Cologne, a German industrial city, the JIVE and MEHRLIN projects conducted tests in five European countries: Denmark, Germany, the United Kingdom, Latvia and Italy. The project spent $€ 125$ million (US\$133 million) and allocated heavy vehicles including 144 hydrogen FC buses and seven large hydrogen fuel gas stations.

The operation of FCVs is relatively quiet and can reduce noise levels in city areas. In public transportation sector around the world, buses are currently operating, and some success stories have proved their continuous improvement in readiness and consistency. However, due to the lack of FCVs hydrogen refueling stations, the infrastructure is still in its infancy.

Besides modelling of the situation in Normandy, France in 2016, some predictions for 2025 were prepared based on the current assessment of the distribution of hydrogen FCvehicles (FCVs) [66]. Cost-benefit analysis shows that the total cost of ownership of hydrogen kangaroos must be halved. High-power vehicles, such as buses and trucks, have played an important role in increasing hydrogen consumption by further expanding the use of FCVs from Normandy to Europe, as well as using cars, buses, and hydrogen-producing trucks other than kangoos. The two cost components (vehicle cost and fuel cost) involved in deploying an electric FC vehicle (FCEV) can be regarded as a vehicle cost component and a fuel cost component, respectively, and the first component a is more effective than the second component. The cost of introducing hydrogen can be reduced by using a small number of large vehicles to travel on a limited point-to-point route or in a smaller geographic area to promote the widespread use of light hydrogen vehicle [67].

Europeans are aware of the low quality air and noise interference caused by public transportation. Although some cities are starting to use electric vehicles, hydrogen $\mathrm{FC}$ buses are still a viable option for most countries that use subsidized diesel buses. Over the past ten years, $84 \mathrm{FC}$ buses operating in 17 cities in 8 European countries have maintained excellent records of flexibility and security. These vehicles can travel up to 300 to 450 kilometers. As a result, there is no need to install infrastructure along the route. If buses and FC cars are mass-produced together, the cost is lower [68].

\section{Conclusion and Recommendation}

The students must always be guided to provide them with stimulus after exposure to the inventive procedure. In order to invent new engineering products, they should focus on efforts to improve, enhance and expand mainstream products to meet social needs, or to merge useful combinations of prevailing products to create new products and finally to apply for patents. The inventions should also be "futurized" to ensure the products could always be updated.

Soon after the world is tragically affected by the coronavirus COVID-19 pandemic, there is an urgent need to design and develop modules for teaching and learning hydrogen fuel cells that could be implemented not only in the physical classroom but also online learning that is free for all and avoids the pandemic.
After examining the suitability of these materials to be implemented in the physical classroom and online learning, it is recommended that a cost-effective and economic teaching and learning of hydrogen fuel cells in the country and/or the region should be developed. The teaching and learning materials could be transformed into the online learning platform that is free for all.

Implementation of the traditional face-to-face teaching is fraught with problems because of the limited period for related programs and difficulty to get a suitable time to do the intervention. This constraint is due to the difficulty of adjusting schoolchildren learning timetables to accommodate the implementation of the new module. Other obstacles to the implementation are the difficulty of getting the support from the school administrators and the availability of the venue.

In the online setting, the introduction part has to be simple, straight to the point, and usually aided with audio-visual media, which are pre-recorded videos from the instructor or merely the shared videos. Tests and game could be done live during the lessons and the students submit their work online. The submission and grading system will be done online. Besides, these blended, interactive online courses with a curriculum created by educators for students, and even educators for educators have the potential to encourage learning, collaboration on projects and hassle-free grading assignments, free for all urban and sub-urban children anywhere and any level, staying safe online and avoiding pandemic crisis.

\section{Acknowledgment}

This work was supported by Grant GP-2019-K003081 under Universiti Kebangsaan Malaysia, Malaysia.

\section{References}

[1] E.J. Kim, H. Kim, "Effect modification of individual- and regional-scale characteristics on heat wave-related mortality rates between 2009 and 2012 in Seoul, South Korea," Science of The Total Environment, 595(Oct 2017), 141-148, 2017, doi:10.1016/J.SCITOTENV.2017.03.248.

[2] S. Nobert, M. Pelling, "What can adaptation to climate-related hazards tell us about the politics of time making? Exploring durations and temporal disjunctures through the 2013 London heat wave," Geoforum, 85, 122-130, 2017, doi:10.1016/J.GEOFORUM.2017.07.010.

[3] P.F. Tan, W.R.W. Daud, L. Halim, M.S. Masdar, "How Ready is Renewable Energy? A Review on Renewable Energy and Fuel Cell Teaching in Schools," in 2017 7th World Engineering Education Forum (WEEF), 236-244, 2017, doi:10.1109/WEEF.2017.8466971.

[4] S.R. Paramati, A. Sinha, E. Dogan, "The significance of renewable energy use for economic output and environmental protection: evidence from the Next 11 developing economies," Environmental Science and Pollution Research, 24(15), 13546-13560, 2017, doi:10.1007/s11356-017-8985-6.

[5] I. Attiaoui, H. Toumi, B. Ammouri, I. Gargouri, "Causality links among renewable energy consumption, $\mathrm{CO} 2$ emissions, and economic growth in Africa: evidence from a panel ARDL-PMG approach," Environmental Science and Pollution Research, 24(14), 13036-13048, 2017, doi:10.1007/s1 1356-017-8850-7.

[6] M.H. Zrelli, "Renewable energy, non-renewable energy, carbon dioxide emissions and economic growth in selected Mediterranean countries," Environmental Economics and Policy Studies, 2016, doi:10.1007/s10018016-0170-5.

[7] L. Nyiwul, "Economic performance, environmental concerns, and renewable energy consumption: drivers of renewable energy development in SubSahara Africa," Clean Technologies and Environmental Policy, 19(2), 437450, 2017, doi:10.1007/s10098-016-1229-5.

[8] J. Constable, L. Moroney, "Economic hazards of a forced energy transition: 
inferences from the UK's renewable energy and climate strategy," Evolutionary and Institutional Economics Review, 14(1), 171-192, 2017, doi:10.1007/s40844-016-0041-6.

[9] N.D. Hensel, "Economic Challenges in the Clean Energy Supply Chain: The Market for Rare Earth Minerals and Other Critical Inputs," Business Economics, 46(3), 171-184, 2011, doi:10.1057/be.2011.17.

[10] V.G. Gude, G.E. Grant, P.D. Patil, S. Deng, "Biodiesel production from low cost and renewable feedstock," Central European Journal of Engineering, 3(4), 595-605, 2013, doi:10.2478/s13531-013-0102-0.

[11] A. Kayahan Karakul, "Educating labour force for a green economy and renewable energy jobs in Turkey: A quantitave approach," Renewable and Sustainable Energy Reviews, 63, 568-578, 2016, doi:10.1016/j.rser.2016.05.072.

[12] X. Zhao, D. Luo, "Driving force of rising renewable energy in China: Environment, regulation and employment," Renewable and Sustainable Energy Reviews, 68, Part 1, 48-56, 2017, doi: 10.1016/j.rser.2016.09.126.

[13] Y.N. Yusoff, K.S. Loh, W.Y. Wong, W.R.W. Daud, T.K. Lee, "Sulfonated graphene oxide as an inorganic filler in promoting the properties of a polybenzimidazole membrane as a high temperature proton exchange membrane," International Journal of Hydrogen Energy, 2020, doi: 10.1016/j.ijhydene.2020.07.026

[14] L. Halim, S.M.M. Meerah, gt, "Science Trainee Teachers' Pedagogical Content Knowledge and its Influence on Physics Teaching," Research in Science \& Technological Education, 20(2), 215-225, 2002, doi:10.1080/0263514022000030462.

[15] C. Cunningham, K. Hester, "Engineering is elementary: An engineering and technology curriculum for children," American Society for Engineering Education., 2007.

[16] C. Cunningham, "Engineering is elementary," The Bridge, 30(3), 11-17, 2009.

[17] F. Shahali, M., Hafizan, E., Halim, L., Rasul, S., Osman, K., Ikhsan, Z., \& Rahim, "BITARA-STEM TRAINING OF TRAINERS' PROGRAMME: IMPACT ON TRAINERS' KNOWLEDGE, BELIEFS, ATTITUDES AND EFFICACY TOWARDS INTEGRATED STEM TEACHING," Journal of Baltic Science Education, 14(1), 2015.

[18] N. Kruea-In, O. Thongperm, "Teaching of Science Process Skills in Thai Contexts: Status, Supports and Obstacles," Procedia - Social and Behavioral Sciences, 141, 1324-1329, 2014, doi:10.1016/j.sbspro.2014.05.228.

[19] B. Hyman, Fundamentals of engineering design, 2002.

[20] N. Zografakis, A.N. Menegaki, K.P. Tsagarakis, "Effective education for energy efficiency," Energy Policy, 36(8), 3226-3232, 2008, doi: 10.1016/j.enpol.2008.04.021.

[21] L. Halim, N. Abd Rahman, R. Zamri, L. Mohtar, "The roles of parents in cultivating children's interest towards science learning and careers," Kasetsart Journal of Social Sciences, 39(2), 190-196, 2018, doi: 10.1016/j.kjss.2017.05.001.

[22] M.A. Brown, Hydrogen and Fuel Cells. Dlm. Introduction to Renewable Energy Technology A Year-Long Science \& Technology Course., Metro Denver WIRED Initiative, Lakewood, 2008.

[23] J. Hersyey, The Eureka Method: How to Think Like an Inventor, McGrawHill Companies, New York, 2012.

[24] P. Hurley, Build Your Own Fuel Cells, Wheelock Mountain Publication, Wheelock VT, 2010.

[25] M.R. Anuar, A.Z. Abdullah, "Challenges in biodiesel industry with regards to feedstock, environmental, social and sustainability issues: A critical review," 58, 2016

[26] D.L. Kgathi, G. Mmopelwa, R. Chanda, K. Kashe, M. Murray-Hudson, "A review of the sustainability of Jatropha cultivation projects for biodiesel production in southern Africa: Implications for energy policy in Botswana," Agriculture, Ecosystems \& Environment, 246, 314-324, 2017, doi:http://dx.doi.org/10.1016/j.agee.2017.06.014.

[27] M. Hafizi, Y.H. Teow, W.L. Ang, A. Mohammad, R. Ngteni, K. Yusof, "Fouling assessment of tertiary palm oil mill effluent (POME) membrane treatment for water reclamation," Journal of Water Reuse and Desalination, 8, jwrd2017198, 2017, doi:10.2166/wrd.2017.198.

[28] W.L. Ang, A.W. Mohammad, N. Hilal, C.P. Leo, "A review on the applicability of integrated/hybrid membrane processes in water treatment and desalination plants," Desalination, 363, 2-18, 2015, doi: 10.1016/j.desal.2014.03.008.

[29] W.L. Ang, A.W. Mohammad, "State of the art and sustainability of natural coagulants in water and wastewater treatment," Journal of Cleaner Production, 262, 121267, 2020, doi: 10.1016/j.jclepro.2020.121267.

[30] I.N. Mohamad, R. Rohani, M.S. Mastar@Masdar, M.T. Mohd Nor, J. Md. Jahim, "Permeation properties of polymeric membranes for biohydrogen purification," International Journal of Hydrogen Energy, 41(7), 4474-4488,
2016, doi: 10.1016/j.ijhydene.2015.08.002.

[31] I.N. Mohamad, R. Rohani, M.T.M. Nor, P. Claassen, M.S. Muhammad, M.S.M. Masdar, M.I. Rosli, “An overview of gas-upgrading technologies for biohydrogen produced from treatment of palm oil mill effluent," Journal of Engineering Science and Technology, 12(3), 725-755, 2017.

[32] K. Balasubramanian, I. Kolmanovsky, B. Saha, "Range maximization of a direct methanol fuel cell powered Mini Air Vehicle using Stochastic Drift Counteraction Optimal Control," in 2012 American Control Conference (ACC), IEEE: 3272-3277, 2012, doi:10.1109/ACC.2012.6315232.

[33] Y.B. Blumer, M. Stauffacher, D.J. Lang, K. Hayashi, S. Uchida, "Nontechnical success factors for bioenergy projects-Learning from a multiple case study in Japan," Energy Policy, 60, 386-395, 2013, doi:10.1016/j.enpol.2013.05.075.

[34] K.M. Keramitsoglou, "Exploring adolescents' knowledge, perceptions and attitudes towards Renewable Energy Sources: A colour choice approach," Renewable and Sustainable Energy Reviews, 59(Supplement C), 1159-1169, 2016, doi: 10.1016/j.rser.2015.12.047.

[35] P. Hurley, Build Your Own Fuel Cells, Wheelock Mountain Publications, 2005

[36] US Departmet of Energy.Fuel Cell Technologies Office, Education And Outreach, (February), 2014.

[37] M. Vowles, Washington State Fuel Cell Education and Demonstration Program (DOE Hydrogen Program), 2004

[38] C. Cooper, DOE Hydrogen Program. 2004 Annual Program Review. Education Overview., (27 May), 2004.

[39] T. Truett, Oak Ridge National Laboratory 2004 DOE Hydrogen, Fuel Cells \& Infrastructure Technologies Program Review: Baseline Program Assessment, 2004.

[40] T. Turner, Fuel Cell Demonstration with Onsite Generation of Hydrogen, (April), 2004

[41] A. Peters, Development And Development And Demonstration Of PEM Fuel Demonstration Of PEM Fuel Cell Educational Program Cell Educational Program For School And University For School And University Communities, 2004.

[42] Lansing Community College, The 2004 DOE Hydrogen, Fuel Cells and Infrastructure Technologies Program Review Lansing Community College Alternative Energy Initiative, 2004.

[43] P. Williamson, Montana Hydrogen Futures Project (New Project), Missoula, U,S., 2004.

[44] Fuel Cells 2000, FUEL CELLS FOR EDUCATION, May 2020.

[45] leXsolar, leXsolar-H2, May 2020.

[46] Keego Technologies LLC, MudWatt NGSS Teacher's Guide. Microbial fuel cells (MFCs) teaching module. Main Module., Keego Technologies LLC, Menlo Park, CA, 2017.

[47] A.D.C. Shannon Root, Keri West, Implementation of the MudWatt ${ }^{\mathrm{TM}}$ Microbial Fuel, Cheney, WA, 2011.

[48] H. Aliverdilou, M.S.J. Ameli, N.B. Moghaddam, "Policy making diagnostics of Iran's fuel cell technology," in PICMET '08 - 2008 Portland International Conference on Management of Engineering \& Technology, IEEE: 698-703, 2008, doi:10.1109/PICMET.2008.4599677.

[49] C.-Y. Huang, C.-C. Chang, "Defing the VET Policy Instruments for Developing the National Innovation System of Fuel Cell Technologies," in 2011 IEEE Green Technologies Conference (IEEE-Green), IEEE: 1-6, 2011, doi:10.1109/GREEN.2011.5754854.

[50] A.Q. Al-Amin, A.F. Ambrose, M.M. Masud, "People purchase intention towards hydrogen fuel cell vehicles: An experiential enquiry in Malaysia," 41(4), 2016.

[51] A. Mahmud, "Evaluation of the solar hybrid system for rural schools in Sabah, Malaysia," Power and Energy (PECon), 2010 IEEE, 2010.

[52] UKM-YSD Chair For Sustainable Development: Zero Waste Technology, UKM-YSD Chair For Sustainable Development: Zero Waste Technology. Thrust area 1: Hydrogen for Power and Steam Generation, Dec. 2018.

[53] H.S. Das, C.W. Tan, A.H.M. Yatim, K.Y. Lau, "Feasibility analysis of hybrid photovoltaic/battery/fuel cell energy system for an indigenous residence in East Malaysia," Renewable and Sustainable Energy Reviews, 76, 1332-1347, 2017, doi: 10.1016/j.rser.2017.01.174.

[54] Y.T. Sin, W.A. Najmi W.M, "Industrial and Academic Collaboration Strategies on Hydrogen Fuel Cell Technology Development in Malaysia," Procedia - Social and Behavioral Sciences, 90, 879-888, 2013, doi: 10.1016/j.sbspro.2013.07.164.

[55] Taiwan shows fuel cell scooter, Malaysia builds its first vehicle, Fuel Cells Bulletin, 2015(1), 2-3, 2015, doi: 10.1016/S1464-2859(15)70004-0.

[56] Toyota shows flagship Lexus LF-FC concept fuel cell car in Tokyo, Fuel Cells Bulletin, 2015(11), 2, 2015, doi: 10.1016/S1464-2859(15)30334-5.

[57] Toyota Mirai fuel cell saloons delivered to first UK customers, Fuel Cells 
Bulletin, 2015(11), 2, 2015, doi: 10.1016/S1464-2859(15)30333-3.

[58] Honda begins sales of Clarity Fuel Cell, first car delivered to METI, Fuel Cells Bulletin, 2016(4), 2, 2016, doi: 10.1016/S1464-2859(16)30069-4.

[59] K. Itaoka, A. Saito, K. Sasaki, "Public perception on hydrogen infrastructure in Japan: Influence of rollout of commercial fuel cell vehicles," International Journal of Hydrogen Energy, 42(11), 7290-7296, 2017, doi:10.1016/j.ijhydene.2016.10.123.

[60] K. Ono, K. Tsunemi, "Identification of public acceptance factors with risk perception scales on hydrogen fueling stations in Japan," International Journal of Hydrogen Energy, 42(16), 10697-10707, 2017, doi:10.1016/j.ijhydene.2017.03.021.

[61] Fuel cell technology providing power to South African schools, Fuel Cells Bulletin, 2015(7), 5-6, 2015, doi:10.1016/S1464-2859(15)30182-6.

[62] FuelCell Energy CHP systems at Connecticut school, California jail, Fuel Cells Bulletin, 2017(2), 5, 2017, doi: 10.1016/S1464-2859(17)30077-9.

[63] Pacific Northwest National Laboratory, National Hydrogen and Fuel Cell Emergency Response Training Resource, 2017.

[64] N.F. Barilo, J.J. Hamilton, S.C. Weiner, "First responder training: Supporting commercialization of hydrogen and fuel cell technologies," International Journal of Hydrogen Energy, 42(11), 7536-7541, 2017, doi: 10.1016/j.ijhydene.2016.06.226.

[65] M. Reijalt, "Hydrogen and fuel cell education in Europe: from when? And where? To here! And now!, Journal of Cleaner Production, 18, S112-S117, 2010, doi:10.1016/j.jclepro.2010.05.017.

[66] J. Brunet, J.P. Ponssard, "Policies and deployment for Fuel Cell Electric Vehicles an assessment of the Normandy project," International Journal of Hydrogen Energy, 42(7), 4276-4284, 2017, doi: 10.1016/j.ijhydene.2016.11.202.

[67] A.E. Farrell, D.W. Keith, J.J. Corbett, "A strategy for introducing hydrogen into transportation," Energy Policy, 31(13), 1357-1367, 2003, doi:10.1016/S0301-4215(02)00195-7.

[68] R. Berger, Fuel Cell Electric Buses, 2017. 